F. Reprod. Fert. (1966) 11, 237-244

\title{
SOME CHEMICAL, IMMUNOCHEMICAL AND ELECTROPHORETIC PROPERTIES OF BOVINE FOLLICULAR FLUID
}

\author{
GLAUDE DESJARDINS, K. T. KIRTON* AND H. D. HAFS \\ Department of Dairy, Michigan State University, \\ East Lansing, Michigan, U.S.A.
}

(Received 5th Fuly 1965, revised 29th September 1965)

\begin{abstract}
Summary. Bovine follicular fluid was compared with blood serum or blood plasma with respect to the concentration of protein and free amino nitrogen, the number of antigens and the number and mobilities of electrophoretic components. The protein concentration of follicular fluid $(7.08 \mathrm{~g} / 100 \mathrm{ml})$ was less than that of blood serum $(9 \cdot 10 \mathrm{~g} / 100 \mathrm{ml})$, but no significant difference existed between the values of free amino nitrogen in the two fluids ( 4.31 and $3.97 \mathrm{mg} / 100 \mathrm{ml}$, respectively).

Rabbit antisera to follicular fluid, blood serum or blood plasma gave several precipitin lines (at least 7, 7 and 8 respectively) when reacted with their homologous antigens in agar-gel-diffusion studies. After absorption with blood serum, there was one antigen (presumably fibrinogen) in blood plasma and follicular fluid that was not found in blood serum. These results were substantiated by immuno-electrophoresis.

Moving boundary electrophoresis in five different buffers revealed at least eight components in follicular fluid and blood serum and at least nine in blood plasma. Minor differences were observed in the electrophoretic mobilities of some components found in both follicular fluid and blood serum.

The results showed that the major macromolecular components of follicular fluid and of blood were similar, but that some minor macromolecular ones may differ.
\end{abstract}

\section{INTRODUCTION}

The chemical composition and the physical nature of follicular fluid have been investigated in several species (Lutwak-Mann, 1954; Olds \& VanDemark, 1957a, b, c; Caravaglios \& Cilotti, 1957; VanDemark, 1958; Zachariae \& Jensen, 1958; Yatvin \& Leathem, 1964). Electrophoretic and immunochemical observations by Shivers, Metz \& Lutwak-Mann (1964) on porcine follicular fluid provided convincing evidence that follicular fluid is largely derived from blood by filtration. This conclusion was in general agreement with previously published reports.

* N.I.H. Predoctoral Fellow. 
Glass (1963) demonstrated that, as in follicular fluid, mammalian ova also possess serum antigens at the time of ovulation. Rondell (1964), Zachariae \& Jensen (1958) and Espy \& Lipner (1965) suggested that alterations of the macromolecular composition of follicular fluid may be associated with ovulation. These observations prompted us to compare the macromolecular compositions of follicular fluid, blood serum and blood plasma in the bovine.

\section{MATERIALS AND METHODS}

\section{Follicular fuid and blood serum}

Follicular fluids and blood sera were obtained from non-pregnant cows immediately after slaughter. Initially, fluids were obtained from thirteen follicles, each containing 0.25 to $0.50 \mathrm{ml}$, to compare with fluids from thirteen follicles each containing 0.51 to $2.50 \mathrm{ml}$. There was no appreciable difference in the concentration of protein or of free amino nitrogen, or in the number of antigens in fluids from small or large follicles. Therefore fluids were pooled from all the follicles with a diameter of at least $5 \mathrm{~mm}$ in each of twenty-nine animals. Blood plasma was obtained from ten non-pregnant cows and ethylenediaminetetra-acetic acid was added to prevent coagulation. Each sample of follicular fluid, blood serum or blood plasma was centrifuged at $5^{\circ} \mathrm{C}$ for $15 \mathrm{~min}$ at $10,000 \mathrm{~g}$ and the supernatant fluids were stored for up to $48 \mathrm{hr}$ at $5^{\circ} \mathrm{C}$ before analysis.

\section{Protein and amino nitrogen}

The protein concentrations of forty-six samples of follicular fluid and of blood sera from twenty-nine cows were determined by the method of Gornall, Bardawill \& David (1949). Free amino nitrogen was determined in the same samples by the method of Harding \& Maclean (1916) after precipitation of proteins by the addition of an equal volume of $10 \%$ trichloracetic acid. Standards for the protein and free amino nitrogen determinations were crystalline bovine serum albumin and alanine, respectively.

\section{Immunological tests}

Normal sera were obtained from rabbits before immunization. Two rabbits were immunized with each of the following bovine antigens: pooled samples of follicular fluid, blood serum, seminal plasma and blood plasma, purified blood albumen, $\alpha-\beta$ - and $\gamma$-globulins and fibrinogen (Nutritional Biochemicals Corp., Gleveland, Ohio, U.S.A.). The follicular fluid, serum and plasma were adjusted to contain $7 \%$ protein and the seminal plasma and purified proteins to $2.5 \%$ protein. An emulsion of $1.0 \mathrm{ml}$ of antigen with $1.0 \mathrm{ml}$ of Freund's complete adjuvant was injected subcutaneously into five suprascapular sites in each rabbit. Two and 4 weeks later, each rabbit was given a similar injection of antigen with Freund's incomplete adjuvant. Antiserum was obtained by cardiac puncture 2 weeks after the last injection.

Precipitation in agar-gel was used to determine the number of precipitins in rabbit antisera and immuno-electrophoresis in agar-gel was used to improve 
the resolution of precipitin lines. These procedures were similar to those described by Hunter \& Hafs (1964a).

\section{Electrophoresis}

Electrophoresis of samples of follicular fluid $(3 \mu \mathrm{l})$ and of blood serum was performed in $\mathbf{0 . 8 5} \%$ agar (Oxoid Ion Agar No. 2, Consolidated Laboratories, Chicago Heights, Illinois, U.S.A.) dissolved in barbital buffer $(\mathrm{pH}=8 \cdot 6$, $\mu=0.0375$ ). A potential of $200 \mathrm{~V}$ with a maximum of $60 \mathrm{~mA}$ was applied for $30 \mathrm{~min}$. The agar strips were then washed, dried and stained, and were scanned in a Spinco Analytrol (Model RB) equipped with a B-2 cam and a $500 \mathrm{~m} \mu$ interference filter. These procedures were modified from those of Cawley \& Eberhardt (1962).

To obtain sufficient protein for moving boundary electrophoresis in a Tiselius Apparatus (American Instrument Co., Inc., Silver Spring, Maryland, U.S.A.), aliquots from each sample of follicular fluid, blood serum and plasma were pooled. Each pooled sample was dialysed for $24 \mathrm{hr}$ against three changes of the electrophoresis buffer at $5^{\circ} \mathrm{C}$ and adjusted to a protein content of 2.5 to $4.0 \%$. For all samples electrophoresis was carried out in five different buffers at $2^{\circ} \mathrm{C}$ (see Table 1), for 50 to $100 \mathrm{~min}$ at $25 \mathrm{~mA}$ in acetate buffer and at $15 \mathrm{~mA}$ in other buffers. Electrophoretic mobilities and relative concentrations of components were estimated by the procedure of Alberty (1948) and by planimetry, respectively.

\section{Protein and amino nitrogen}

\section{RESULTS}

The mean concentration of protein $( \pm$ S.E. $)$ in forty-six samples of follicular fluid $(7.08 \pm 0.04 \mathrm{~g} / 100 \mathrm{ml})$ was significantly less than in blood serum of the same cows $(9 \cdot 10 \pm 0 \cdot 18 \mathrm{~g} / 100 \mathrm{ml}, P<0 \cdot 01)$. The free amino nitrogen concentrations in follicular fluid $(4.31 \pm 0.04 \mathrm{mg} / 100 \mathrm{ml})$ and blood serum $(3.97 \pm 0.08)$ did not differ greatly $(P>0.05)$. The concentrations of protein or free amino nitrogen in blood serum were highly correlated with those in follicular fluid $(r>0.98 ; P<0.01)$.

\section{Agar-gel-diffusion studies}

Rabbit antiserum to bovine follicular fluid (anti-follicular fluid serum) reacted with follicular fluid to form at least seven precipitin lines in agar-geldiffusion, six of which are visible in Pl. 1, Fig. 1. Similar studies of rabbit antiserum to bovine blood serum (anti-blood serum) and to bovine blood plasma (anti-blood plasma) also resulted in at least seven precipitin lines which were very similar in their position and arrangement to those illustrated for follicular fluid. A single precipitin line resulted when anti-follicular fluid was absorbed with normal bovine blood serum, according to the method described by Bjorklund (1952), and then diffused against follicular fluid. This single line appeared to be identical to that marked by an arrow in Pl. 1, Fig. 1. When blood plasma was used in place of blood serum in similar absorptions, no precipitin lines developed.

An aliquot of pooled follicular fluid was frozen at $-20^{\circ} \mathrm{C}$ and thawed with 
the result that a precipitate formed. These samples were centrifuged and antiserum was prepared against the supernatant fluid. When this antiserum was absorbed with normal blood serum and diffused against normal follicular fluid, no precipitin lines developed. Thus, the single precipitin line observed in Pl. 1, Fig. 2 was probably dependent upon the material precipitated from follicular fluid by freezing and thawing. An alternate 'freeze-thaw' procedure has been used to isolate fibrinogen from blood plasma (Haurowitz, 1963).

Rabbit immune sera prepared against crystalline albumin, $\alpha-\beta$ - and $\gamma-$ globulins and fibrinogen resulted in at least $3,3,3,1$ and 5 precipitin lines, respectively, when diffused against bovine follicular fluid in agar-gel. Supernatant fluid from follicular fluid that was frozen at $-20^{\circ} \mathrm{C}$ and thawed replaced follicular fluid in agar-gel-diffusions; similar precipitin lines formed except that no lines formed with anti-fibrinogen serum. Agar-gel-diffusions of albumin, $\alpha$-, $\beta$ - and $\gamma$-globulins, fibrinogen, follicular fluid and blood plasma against anti-follicular fluid which was absorbed with blood serum resulted in one precipitin line for blood plasma, follicular fluid, fibrinogen and $\beta$-globulin (e.g. Pl. 1, Fig. 2). The line for $\beta$-globulin may have been due to fibrinogen contamination of the $\beta$-globulin since the two components were closely similar in their electrophoretic behaviour.

No precipitations were observed in control diffusions in which rabbit blood serum was substituted for the various antisera.

\section{Immunochemical cross-reactions}

Diffusions of anti-follicular fluid immune serum against bovine seminal plasma resulted in at least three precipitin lines (Pl. 1, Fig. 3). All these lines were eliminated when the anti-follicular fluid was absorbed with bovine blood serum before diffusion. Subsequently, agar-gel-diffusion plates were designed to test for precipitations between antisera to follicular fluid, blood serum and seminal plasma and the three antigens. These results (e.g. Pl. 1, Fig. 3) indicated that only two of the seven detectable antigens in seminal plasma were present in either follicular fluid or blood serum. These results suggested that seminal plasma antigens may be quite different from those of blood plasma or follicular fluid. Bovine sperm-specific proteins, prepared according to the procedures of Hunter \& Hafs (1964b), failed to cross-react with anti-follicular fluid serum in agar-gel diffusions.

\section{Immuno-electrophoresis}

Electrophoresis of follicular fluid in agar-gel, followed by diffusion against anti-follicular fluid serum, resulted in at least eight precipitations (Plate 2).

Diagrams (left) and photographs (right) of agar-gel-double-diffusion plates.

Fig. 1. Centre well contained antiserum to follicular fluid (AFF) and peripheral wells contained a serial dilution of follicular fluid (FF) from $1: 1$ in Well 1 to $1: 32$ in Well 6 . FIG. 2. Centre well contained AFF absorbed with blood serum and peripheral wells contained FF, fibrinogen (FIB), $\alpha$-globulin $(\alpha-\mathrm{G}), \beta$-globulin $(\beta$-G), $\gamma$-globulin $(\gamma-\mathrm{G})$, or blood plasma (BP).

FIG. 3. Centre well contained AFF and peripheral wells contained seminal plasma (sP), blood serum (BS), and follicular fluid (FF). 
PI.ITE I
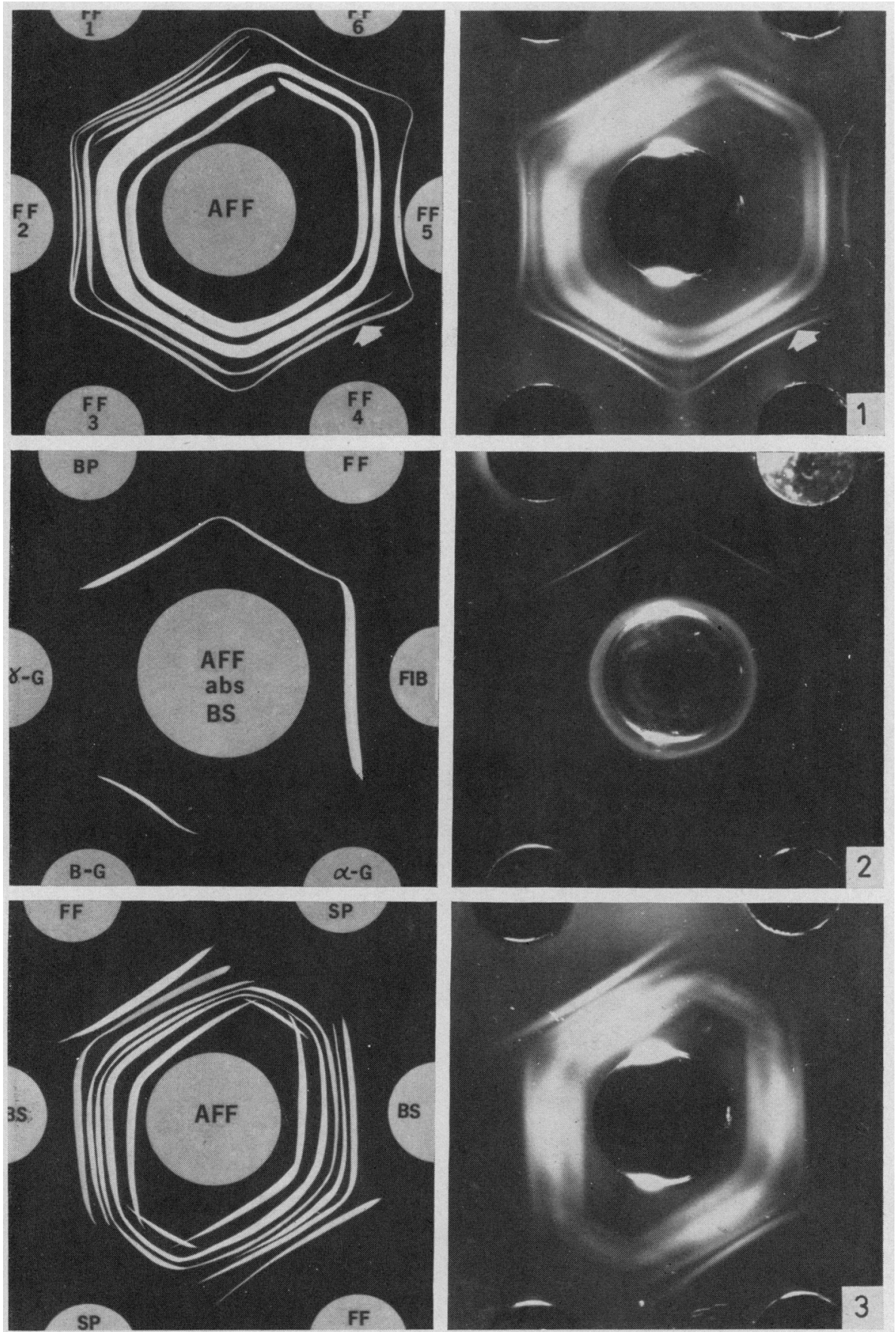


\section{PIATE 2}
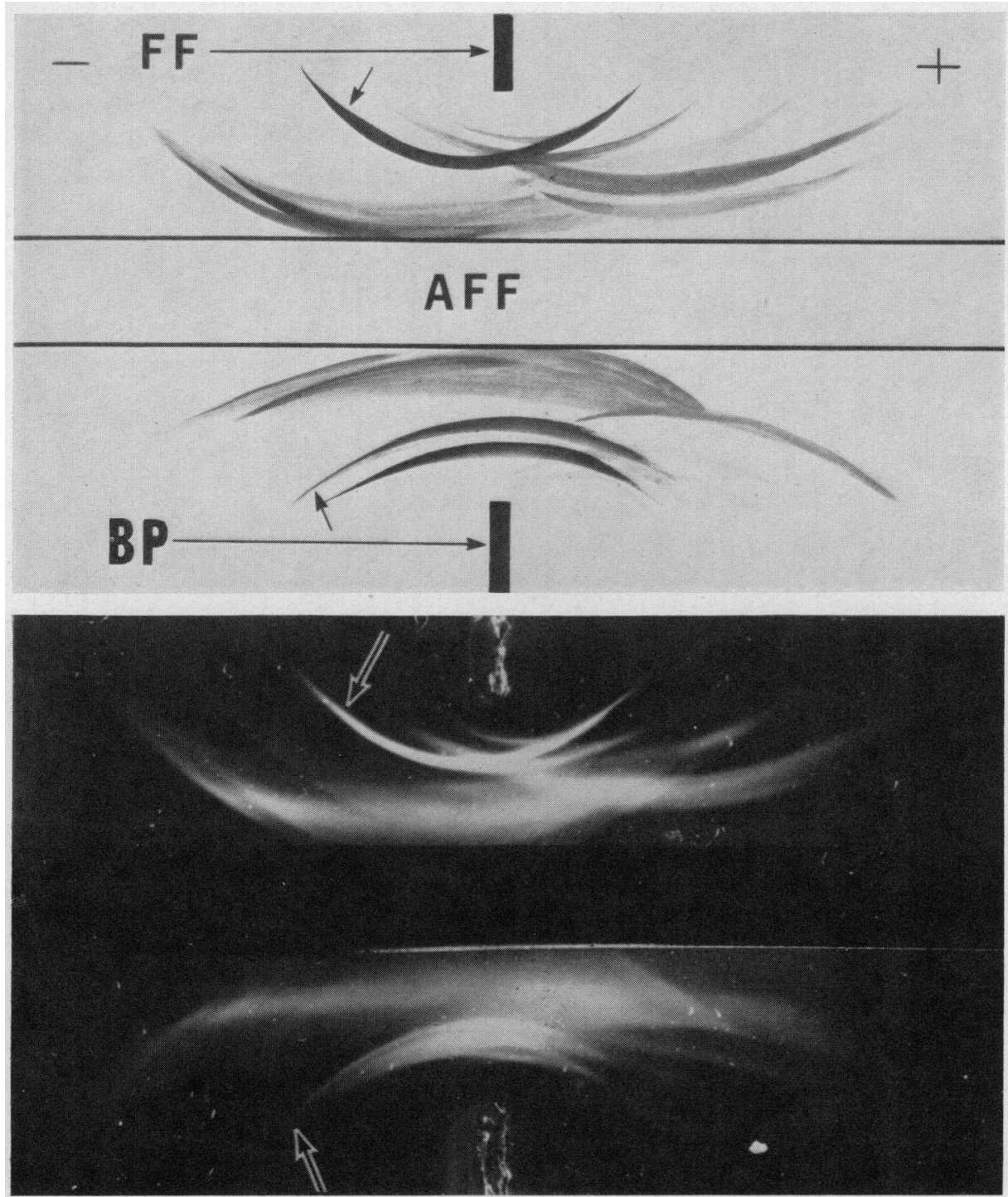

Diagram (top) and photograph (bottom) of immuno-electrophoresis plate. Blood plasma ( $\mathrm{BP}$-bottom slit) and follicular fluid ( $\mathrm{FF}$ - top slit) were clectrophoresed. Cientre trough was then filled with antiserum to follicular fluid (AFF). The diagonal arrows indicate the component (probably fibrinogen) which remained when $A F F$ was absorbed with blood serum. 
All lines except the one indicated by arrows were eliminated when antifollicular fluid was absorbed with blood serum before agar-gel-diffusion. When the supernatant fluid from 'frozen-thawed' follicular fluid was electrophoresed and diffused against anti-follicular fluid serum, the lines marked by arrows did not appear and absorption of the immune serum in these plates eliminated all precipitations.

\section{Electrophoresis}

Agar-gel-electrophoresis of follicular fluid, blood serum and blood plasma revealed five components. There were no apparent differences between the three fluids regarding the positions or magnitudes of the five components.

TABLE 1

ELECTROPHORETIC COMPONENTS OF FOLLICULAR FLUID (FF), BLOOD SERUM (BS) AND BLOOD PLASMA (BP)

\begin{tabular}{|c|c|c|c|}
\hline Buffer & Fluid & $\left.\begin{array}{c}\text { Field } \\
\text { strength } \\
(\text { V/cm } \\
2\end{array}\right)$ & $\begin{array}{c}\text { Electrophoretic mobilities of measurable components* } \\
\left(\mathrm{cm}^{2} / \mathrm{V} / \mathrm{sec} \times 10^{-5}\right)\end{array}$ \\
\hline $\begin{array}{l}\text { Acetate } \\
(\mathrm{pH}=5 \cdot 40)\end{array}$ & $\begin{array}{l}\text { FF } \\
\text { BS } \\
\text { BP }\end{array}$ & $\begin{array}{l}2.5 \\
2 \cdot 3 \\
2 \cdot 3\end{array}$ & $\begin{array}{l}1 \cdot 0(45), 2 \cdot 4(55) \\
1 \cdot 3(36), 2 \cdot 6(64) \\
2 \cdot 8(43), 5 \cdot 6(57)\end{array}$ \\
\hline $\begin{array}{l}\text { Phosphate } \\
(\mathrm{pH}=6 \cdot 60)\end{array}$ & $\begin{array}{l}\text { FF } \\
\text { BS } \\
\text { BP }\end{array}$ & $\begin{array}{l}5 \cdot 6 \\
4 \cdot 4 \\
4 \cdot 8\end{array}$ & $\begin{array}{l}0 \cdot 6,1 \cdot 3,2 \cdot 0(17), 2 \cdot 3,2 \cdot 8,3 \cdot 5(15), 4 \cdot 0,4 \cdot 2,4 \cdot 9(68) \\
1 \cdot 6(23), 2 \cdot 6(23), 4 \cdot 0(55) \\
0 \cdot 6(31), 1 \cdot 9,2 \cdot 5(6), 4 \cdot 6,5 \cdot 6(63)\end{array}$ \\
\hline $\begin{array}{l}\text { Phosphate } \\
(\mathrm{pH}=7 \cdot 80)\end{array}$ & $\begin{array}{l}\text { FF } \\
\text { BS } \\
\text { BP }\end{array}$ & $\begin{array}{l}5 \cdot 0 \\
4 \cdot 4 \\
4 \cdot 4\end{array}$ & $\begin{array}{l}1 \cdot 1(18), 2 \cdot 7(12), 3 \cdot 4(4), 4 \cdot 7,5 \cdot 7(65) \\
1 \cdot 2(27), 2 \cdot 5(6), 3 \cdot 3(9), 3 \cdot 9,4 \cdot 6(58) \\
0.9(18), 1 \cdot 4,2 \cdot 5(24), 3 \cdot 2,3 \cdot 8,4 \cdot 8(12), 5 \cdot 6,6 \cdot 4(46)\end{array}$ \\
\hline $\begin{array}{l}\text { Barbital } \\
(\mathrm{pH}=8 \cdot 60)\end{array}$ & $\begin{array}{l}\text { FF } \\
\text { BS } \\
\text { FF } \\
\text { F }\end{array}$ & $\begin{array}{l}6 \cdot 3 \\
5 \cdot 8 \\
6 \cdot 5 \\
6 \cdot 3\end{array}$ & $\begin{array}{l}1 \cdot 1,1 \cdot 8(16), 2 \cdot 6(25), 3 \cdot 1,4 \cdot 1,5 \cdot 1(8), 6 \cdot 1,6 \cdot 8(51) \\
1 \cdot 0,1 \cdot 6(23), 2 \cdot 6(20), 3 \cdot 4,4 \cdot 5(14), 5 \cdot 4,6 \cdot 6,6 \cdot 7(43) \\
1 \cdot 1,1 \cdot 6(19), 2 \cdot 2,2 \cdot 8(33), 4 \cdot 1,4 \cdot 9(14), 5 \cdot 1,5 \cdot 8,6 \cdot 7(35) \\
1 \cdot 2,2 \cdot 3(21), 2 \cdot 8(16), 3 \cdot 4,4 \cdot 5,5 \cdot 2(14), 6 \cdot 1,6 \cdot 8(49)\end{array}$ \\
\hline $\begin{array}{l}\text { Ammonia } \\
(\mathrm{pH}=9 \cdot 80)\end{array}$ & $\begin{array}{l}\text { FF } \\
\text { BS } \\
\text { BP }\end{array}$ & $\begin{array}{l}5 \cdot 6 \\
5 \cdot 4 \\
5 \cdot 1\end{array}$ & $\begin{array}{l}2 \cdot 3,3 \cdot 5,4 \cdot 6(39), 5 \cdot 2(8), 6 \cdot 2,7 \cdot 1,8 \cdot 8,9 \cdot 5(53) \\
3 \cdot 3(8), 5 \cdot 0(21), 7 \cdot 0,10 \cdot 0(71) \\
4 \cdot 7,5 \cdot 5(15), 6 \cdot 1(11), 7 \cdot 5,10 \cdot 5(74)\end{array}$ \\
\hline
\end{tabular}

* Percentage composition of major components given in parentheses.

$\dagger$ Follicular fluid 'frozen-thawed' before electrophoresis.

The results of moving boundary electrophoresis of the three fluids in different buffers (two acidic, two basic and one neutral) are listed in Table 1, and electrophoretic patterns for barbital buffer, which appeared to give the best resolution, are illustrated in Text-fig. 1. Some differences were observed in the number of components separated in each buffer using follicular fluid, blood serum or blood plasma, but they were restricted to minor components. The number of major components was identical in the three fluids. Some major differences were observed in electrophoretic mobilities of comparable components of follicular fluid, blood serum and blood plasma; but they did not necessarily reflect major differences in protein composition. The outstanding feature of the results from moving boundary electrophoresis was the similarity 
of the patterns for follicular fluid, blood serum and blood plasma (e.g. Text-fig. 1) in each buffer. Fibrinogen in blood plasma has been reported to migrate with globulin and was presumably identifiable in barbital buffer with a mobility of $2 \cdot 8 \mathrm{~cm}^{2} / \mathrm{V} / \mathrm{sec} \times 10^{-5}$ (arrows, Text-fig. 1). Results using barbital buffer (Table 1) showed that the percentage of globulin was less in blood serum $(20 \%)$ than in blood plasma $(33 \%)$, and less in follicular fluid that was frozen at $-20^{\circ} \mathrm{C}$ and thawed $(16 \%)$ than in fresh follicular fluid $(25 \%)$.
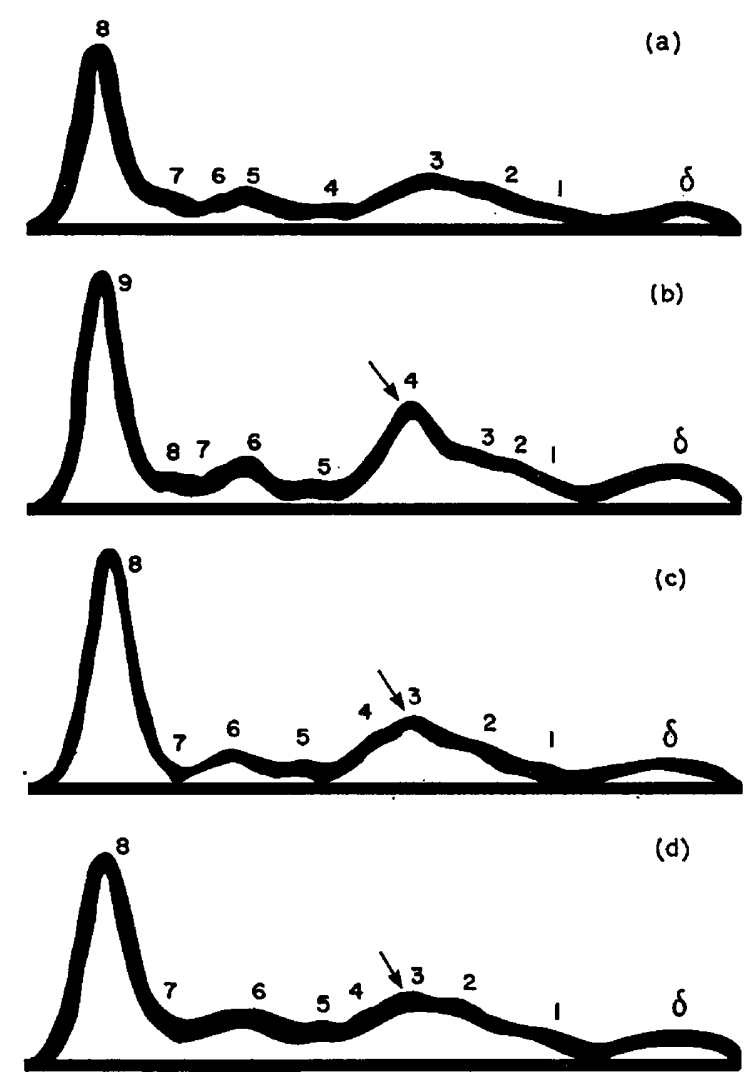

TEXT-FIG. 1. Diagrams of moving boundary electrophoresis patterns of (a) blood serum, (b) blood plasma, (c) follicular fluid, and (d) frozen-thawed follicular fluid. Arrows indicate the component which may have included fibrinogen.

\section{DISCUSSION}

The limited chemical determinations revealed no major differences between follicular fluid and blood serum, except that blood serum contained significantly more protein. The very high correlations in the same animals between the concentrations of protein and free amino nitrogen in blood serum and those in follicular fluid suggested that the latter was derived from the former.

Extensive immunochemical analyses revealed no major difference between follicular fluid, blood serum and blood plasma, except that follicular fluid and blood plasma, but not blood serum, possessed a component which resembled 
fibrinogen. Shivers et al. (1964) found two antigens in porcine blood serum that could not be identified in porcine follicular fluid, and, as in the present results in the bovine, they reported a component similar to fibrinogen in porcine follicular fluid.

If proteins (antigens) were secreted by the follicle, they were not distinguishable from those found in the blood used in this study. There are several reports in the literature, however, which suggest that follicular fluid may contain certain specific proteins. Waldeyer (1870) and Zondek \& Aschheim (1926) considered follicular fluid to be derived primarily from secretions of the granulosa cells, but also from a filtration of blood through the theca interna. Thielen (1953) speculated that partial dissolution of the cytoplasm from granulosa cells contributed to the formation of follicular fluid. Additional evidence that the granulosa cells are involved in follicular fluid production was provided by Selye (1947) who reported that follicular fluid was absent when granulosa cells were destroyed by X-irradiation. Although the biochemical and immunochemical results reported here demonstrated major similarities between protein components of blood and of follicular fluid, some minor differences between them were indicated by moving boundary electrophoresis. It is possible, therefore, that secretions from the follicle may contribute specific macromolecules to follicular fluid, but that the secretory process may be a minor one in the formation of bovine follicular fluid.

The results of these biochemical, immunochemical and electrophoretic studies support the theory that the follicle serves as a special reservoir and that its limiting membrane has unusual permeability to blood proteins. Such permeability has been attributed to the basal membrane of the granulosa layer (Mansini et al., 1962). In addition, these results provide strong support for the conclusion of previous researchers (e.g. Shivers et al., 1964) that follicular fluid is derived chiefly from blood, probably by a process analogous to filtration.

\section{ACKNOWLEDGMENTS}

This paper is Journal Article No. 3666 from the Michigan Agricultural Experiment Station. Bovine sperm-specific proteins were kindly provided by Dr A. G. Hunter, Department of Dairy Husbandry, University of Minnesota, St. Paul.

\section{REFERENCES}

Alberty, R. A. (1948) An introduction to electrophoresis. I. Methods and calculations. F. chem. Educ. $25,426$.

BJORKLUND, B. (1952) Specific inhibition of precipitation as an aid in antigen analysis with gel diffusion method. Proc. Soc. exp. Biol. Med. 79, 319.

Caravaglios, R. \& Cilotti, R. (1957) A study of the proteins in the follicular fluid of the cow. $\mathcal{F}$. Endocr. 15, 273.

Cawley, L. P. \& Eberhardt, L. (1962) Simplified gel electrophoresis. I. Rapid technique applicable to the clinical laboratory. Tech. Bull. Med. Technol. 32, 165.

EsPEy, L. L. \& LIPNER, H. (1965) Enzyme induced rupture of rabbit Graffian follicle. Am. F. Physiol. 208, 208.

GLAss, L. (1963) Transfer of native and foreign serum antigens to oviducal mouse eggs. Am. Zoologist, $3,135$.

Gornale, A. G., Bardawill, C. J. \& David, M. M. (1949) Determination of serum proteins by means of the biuret reaction. F. biol. Chem. 177, 751. 
HARding, V. J. \& MACLEAN, R. M. (1916) A colorimetric method for the estimation of amino-acid nitrogen. II. Application to the hydrolysis of proteins by pancreatic enzymes. F. biol. Chem. 24, 503.

Haurowrtz, F. (1963) The chemistry and function of proteins. p. 193. Academic Press, New York.

Hunter, A. G. \& Hafs, H. D. (1964a) Antigenicity and cross-reactions of bovine spermatozoa. 7 . Reprod. Fert. 7, 357.

Hunter, A. G. \& Hafs, H. D. (1964b) Some physicochemical properties of saline soluble proteins in bovine spermatozoa. F. Reprod. Fert. 8, 243.

Lutwak-ManN, C. (1954) Note on the chemical composition of bovine follicular fluid. F. agric. Sci. 44, 477.

Mansini, R. E., Vilar, O., Dellacha, J. M., Davidson, O. W., Gomez, G. J. \& Alvarez, B. (1962) Extravascular distribution of fluorescent albumin, globulin, fibrinogen in connective tissue structures. 7. Histochem. Cytochem. 10, 194.

Olds, D. \& VanDemark, N. L. (1957a) The behavior of spermatozoa in luminal fluids of bovine female genitalia. Am. F. vet. Res. 18, 603.

Olds, D. \& VanDemark, N. L. (1957b) Composition of luminal fluids in bovine female genitalia. Fert. Steril. 8, 345.

Olds, D. \& VanDemark, N. L. (1957c) Luminal fluids of bovine female genitalia. 7. Am. vet. med. Assoc. 131, 555.

Rondell, P. A. (1964) Follicular pressure and distensibility in ovulation. Am. F. Physiol. 207, 590.

SELYE, H. (1947) Textbook of endocrinology, p. 338. Acta Endocrinologica, Univ. de Montreal, Montreal.

Shivers, C. A., Metz, C. B. \& Lutwak-ManN, C. (1964) Some properties of pig follicular fluid. 7. Reprod. Fert. 8, 115.

Thielen, R. von (1953) Blutgefässe und follikelepitithel in ihrer funktionellen bedeutung für die bildung des liquors in den ovarialfollikeln. Annls Univ. Sarav. Medizin, 1, 127.

VanDemark, N. L. (1958) Spermatozoa in the female genital tract. Int. F. Fert. 3, 220.

WALDEYER, W. (1870) Eierstock und Ei. Ein beitrag zur anatomie und entwicklungsgeschichte der sexualorgane, pp. 48-69. Engelmann, Leipzig.

Yatvin, M. B. \& LeAthem, J. H. (1964) Origin of ovarian cyst fluid: studies on experimentally induced cysts in the rat. Endocrinology, 75, 733.

Zachartae, F. \& Jensen, C. E. (1958) Studies on the mechanism of ovulation. Histochemical and physico-chemical investigations on genuine follicular fluids. Acta endocr., Copenh. 27, 343.

Zondek, B. \& Aschнeim, S. (1926) Zur Ovarimus Funktion des. III. Die Entstehung des Follikelsaftes. Klin. Wschr. 5, 400. 